Jurnal Teknologi Laboratorium

Vol.8, No.2, September 2019, pp. $41-46$

ISSN 2580-0191 (Online), ISSN $2338-5634$ (Print)

DOI: $10.29238 /$ teknolabjournal.v8i2.167

Journal homepage: https://www.teknolabjournal.com/index.php/Jt//index

\title{
Chymase level in dengue virus infection with or without positive Non-Structural 1 (NS1)
}

Menik Kasiyati ${ }^{1 a^{*}}$, Jusak Nugraha ${ }^{2 b}$, Hartono Kahar ${ }^{2 c}$

${ }^{1}$ Postgraduates School of Immunology Airlangga University Surabaya, Indonesia

${ }^{2}$ Department of Clinical Pathology Faculty of Medicine Airlangga University/Dr. Sutomo General Academic Hospital, Surabaya, Indonesia

a Email address: rifani.2010@gmail.com

b Email address: jusak.nugraha@yahoo.com

c Email address: hartono1@gmail.com

\section{HIGHLIGHTS}

There were no significant differences in chymase levels between groups NS1 (+) and NS1 (-)

\section{ARTICLE INFO}

\section{Article history}

Received Date: April 29th 2019

Revised Date: May 14 ${ }^{\text {th }}, 2019$

Accepted Date: September $27^{\text {th }}, 2019$

\section{Keywords:}

Thrombocytopenia

Chymase

NS1

Dengue virus infection

\section{A B S T R A C T}

Thrombocytopenia, leukopenia, and monocytosis are laboratory parameters in the diagnosis of dengue virus infection. In addition to monocyte cells, mast cells also play a role in the innate immune response, where degranulation of mast cells will occur, which will secretion the active vaso mediator, Chymase. Chymase has a role in increasing vascular permeability resulting in plasma leakage in patients with dengue virus infection to determine the number of platelets, leukocytes, monocytes and chymase levels in patients with dengue infection in the acute phase. The platelet count mean in NS1 (+) was 132,140 cells / mm3 and the platelet count in the NS1 group was (-) 176,000 cells $/ \mathrm{mm}^{3}$. The mean leukocytes NS1 (+) showed results of 4,350 cells $/ \mathrm{mm}^{3}$ and NS1 (-) 5,250 cells $/ \mathrm{mm}^{3}$. The mean monocyte NS1 (+) monocyte count was $8.26 \%$, and NS1 (-) group was $8.76 \%$. There were no significant differences in platelet counts, leukocytes and monocytes between NS1 (+) and NS1 (-) (P value> 0.05). The mean Chymase NS1 (+) 23.48, NS1 (-) $23.05 \mathrm{ng} / \mathrm{mL}$ and the control group $1.47 \mathrm{ng} / \mathrm{mL}$.

\section{${ }^{*}$ Corresponding Author:}

Menik Kasiyati

Jurusan Analis Kesehatan, Poltekkes Kemenkes Yogyakarta

JI. Ngadinegaran MJ III/62, Yogyakarta, Indonesia

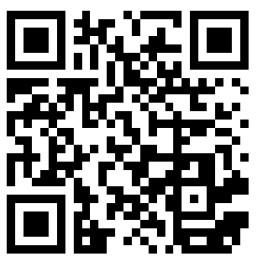




\section{INTRODUCTION}

World Health Organization (WHO) estimates that $40 \%$ of the world's population of around 2.5 billion people living in tropical and sub-tropical regions are at risk of contracting dengue virus infection. In Indonesia, this disease has been occurring every year for 45 years. ${ }^{1}$ This virus consists of four types of serotypes (DENV1, DENV2, DENV3 and DENV4). ${ }^{2}$ Dengue virus infection in humans results in a varied spectrum of clinical manifestations. Most DENV infections are asymptomatic or have mild symptoms, with a small proportion experiencing Dengue Hemorrhagic Fever (DHF) and Dengue Shock Syndrome (DSS). Clinical manifestations for DHF and DSS include dengue fever, thrombocytopenia, vascular permeability and plasma leakage. ${ }^{3}$

The innate immune response awakens immediately after the infected Aedes mosquito inoculates DENV into the skin. Immune cells that are targeted by DENV are myeloid groups, namely phagocytic cells, including dendritic cells and monocyte cells. Monocytes and DC cells will be recruited significantly to the skin that has DENV infection. Monocytes and DCs can detect the presence of DENV using pathogen recognition receptors (PRRs), including TLRs, RLRs and CLRs. Activation of PRRs by DENV will activate intracellular pathway signaling which will induce inflammatory cytokines and anti-viral immunity through the production of type I Interferon (IFN) namely IFN $\alpha$ and IFN $\beta .4$

Like Langerhans dendritic cells, mast cells also interact with DENV in the early stages of infection. However, cell mast interactions with DENV differ from the type of Antigen-Presenting Cell (APC), which is the target of infection. Mast cells will experience degranulation within a few minutes after being exposed to DENV and will produce cytokines in the next few hours. Degranulation of mast cells will produce inflammatory mediators. $\frac{5}{}$ Chymase from mast cells will support increased vascular permeability both indirectly with the production of bradykinin, as well as the possibility of direct mechanism. ${ }^{6}, 7$ Chymase can cause degradation of junction cells, which can cause increased permeability. - The mechanism of action of the chymase is evident that tight junction protein (for example, Claudin 4, Claudin 5 and Occludin) are closely related to chymase both directly and indirectly. It is clear that the degradation of several proteins supports inflammation by migrating leukocytes through the endothelium. $\cdot, \frac{910}{}$

\section{MATERIALS AND METHOD}

The sample was collected from patients with dengue virus infection in Dr. Darsono Hospital, Pacitan. Inclusion criteria included patients aged 17-60 years, having fever for 2-7 days, NS1 examination results showing positive (+) and NS1 (-) diagnosing dengue virus infection in medical records and willing to sign informed consent. While the exclusion criteria are patients with dengue fever infection who meet the inclusion criteria with asthma, urticaria and diarrhea. The sample was 59 patients during January - March 2019. Patients were taken for blood on the first day of hospital admission for NS1 examination and complete blood examination in the laboratory. The serum is collected from patients who have diagnosed DF / DHF based on the rules of the World Health Organization (WHO) and examined Chymase levels at the Pathology Laboratory of the Gadjah Mada University in Yogyakarta. Approval of ethical clearance was obtained from the Faculty of Dentistry of Airlangga University Surabaya with Number 004 / HRECC.FODM / I 2019. NS1 examination was carried out with the Panbio early detection brand rapid test. Chymase examination is done using Human Chymase 1, Mast Cell ELISA KIT from Bioassay Technology Laboratory.

\section{RESULTS AND DISCUSSION}

The number of samples obtained was 59 samples consisting of 49 samples with positive NS1 results (+) and ten samples with negative NS1 (-). The results showed that the NS1 (+) group was dominated by a male as much as $67.3 \%$ (33 people), while female $32.7 \%$. There was a significant relationship between sex and dengue fever, where the results showed that men had a risk of 4.99 times higher than a woman. ${ }^{11}$ Moreover, men have relatively higher work activities and mobilization than women. $\frac{12}{}$

Table 1. Characteristics of DHF patients 


\begin{tabular}{lccc}
\hline \multirow{2}{*}{ Characteristics $(\mathrm{n}=59)$} & \multicolumn{2}{c}{ Non-Structural (NS) 1} & \multirow{2}{*}{ P value } \\
\cline { 2 - 3 } & Positive $(+)$ & Negative $(-)$ & \\
\hline NS1 Test & 49 & 10 & $0,301^{* *}$ \\
Gender & & & \\
$\quad$ Male & $33(67,3 \%)$ & $5(50 \%)$ & \\
$\quad$ Female & $16(32,7 \%)$ & $5(50 \%)$ & \\
Age Group & & & $0,178^{*}$ \\
$\quad$ Late adolescent (17-25) & $19(38,8 \%)$ & $1(10 \%)$ & \\
$\quad$ Young adult (26-35) & $10(20,4 \%)$ & $6(60 \%)$ & \\
$\quad$ Late adult (36-45) & $10(20,4 \%)$ & 0 & \\
$\quad$ Early elderly (46-55) & $10(20,4 \%)$ & $3(30 \%)$ & \\
& & & \\
\hline
\end{tabular}

Grouping characteristics by age, in the NS1 (+) group, was dominated by late adolescents (17-25 years), as many as $38.8 \%$ (19 people). This is in line with the results of the 2017 study by Deborah and Joshi in 2018, showing that there was an increase in the distribution of dengue fever in adolescents and adults. Age is one of the internal factors related to a person's behaviour or community. Age is related to daily activities inside and outside because Aedes $S p$ has a biting habit in the morning and evening. ${ }^{11}$ The results of different tests for the sex group and age between NS1 $(+)$ and NS1 (-) showed that there were no significant differences. This happens because NS1 affects the severity of dengue disease but does not depend on the sex and age of the host.

Table 2. Blood Test Result of DHF Patients

\begin{tabular}{lcccc}
\hline & \multicolumn{2}{c}{ Non-Structural (NS) 1} & P value & Normal \\
Value
\end{tabular}


still in normal value, which is consistent with the Jatmiko study, 2018 where this was due to the recent course of the disease (the fever of the research subjects averaged four days) and the degree of disease that was not severe. Leukopenia in dengue virus infection occurs due to severe bone marrow suppression and occurs in infections that last longer and close to the healing phase. $\frac{13}{-1}$

The results of platelet count in the NS1 (+) group experienced a slight decrease of 132,140 cells $/ \mathrm{mm} 3$, while in the NS1 (-) group it was still within the normal range of $176,000 \mathrm{cells} / \mathrm{mm} 3$. The different platelet test between NS1 (+) and NS1 (-) groups shows the results of the value of P>0.05, which means there is no significant difference. This can occur because many things affect the occurrence of thrombocytopenia in patients with dengue virus infection, including bone marrow suppression, platelet sequestration, megakaryocyte infection, destruction of platelets due to the presence of antiplatelet autoantibodies, and platelet apoptosis. The interaction between these factors and the use of K3EDTA anticoagulants could be the cause of no significant differences between NS1 (+) and NS1 (-). $11, \underline{14}$

The results of a differential count examination, especially the number of lymphocytes and basophils did not increase. Monocyte cell counts had a slight increase where on the NS1 (+) group monocyte count was $8.26 \%$ and NS1 (-) group was $8.76 \%$. This is consistent with the study of Tsai et al., 2017, which states that monocytosis (a significant increase in the number of monocytes) occurs starting on the fifth day. The number of monocytes will continue to increase on the sixth and seventh days after a fever. Monocytes are the main target of the dengue virus, the dengue virus that enters the monocytes will increase cross-reactive antibodies by antibodies which increases in number. Monocytosis, along with thrombocytopenia, is the initial guide and is consistent in the diagnosis of dengue and severe dengue markers. ${ }^{12}$ Activated platelets are containing the dengue virus form aggregations with monocytes during the critical stages of the disease. This shows the possible role of cleansing the virus and the causes of thrombocytopenia implemented by innate phagocytic immune cells. Sequential sequences of events including low platelet counts and transient monocytosis, increasing phagocyte activity during dengue virus infection, can cause the release of large numbers of dissolved factors to induce DHF. 15

The results of different tests on complete blood test parameters did not show a significant difference. This happens because the infection of the dengue virus is still in the initial phase, so excessive destruction has not occurred..$^{11}$

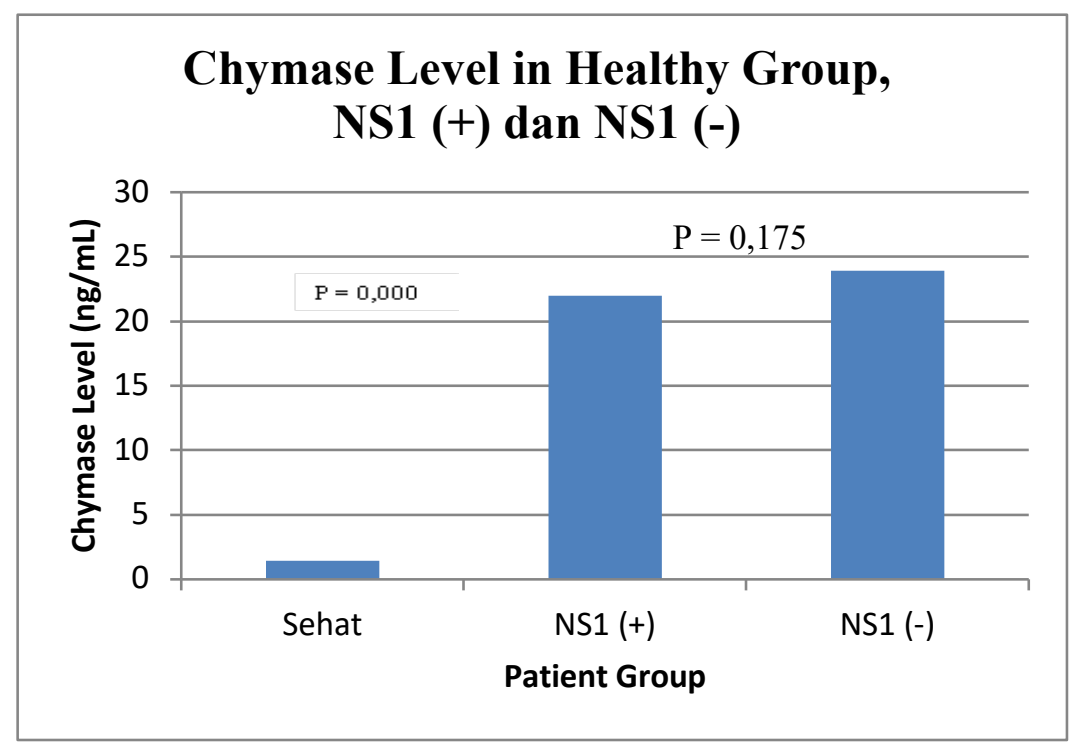

Figure 1. Chymase Levels in the Control Group, DHF Patients with NS1 (+) and NS1 (-)

Chymase levels in patients in the NS1 positive $(+)$ group $(n=49)$ showed no significant difference in the NS1 negative group $(n=10)$. From the figure 1, it can be explained that the chymase level in the NS1 (+) group has an average that is almost the same as the NS1 (-) group. Based on statistical tests with the one-way ANOVA test obtained a value of $P$ value $>0.05$ which can be concluded that there is no significant difference between the chymase levels in the NS1 (+) and NS1 
(-) groups. The results showed a significant difference between chymase levels in the control group with NS1 (+) and between the control group and NS1 (-) group.

Mast cells can produce many vasoactive mediators that have a function in inducing vascular permeability. Some of them are stored and can act almost instantly on the vascular endothelium, TNF, protease (tryptase and chymase) and heparin. Other vasoactive factors include leukotriene, prostaglandin, VEGF. With their activation, the factors released by mast cells act together to promote the degradation of junction cells, plasma leakage and oedema in tissues. The results of the study are not following the research reported by previous researchers that chymase levels will increase very significant in DF (tenfold) and DHF (thirty-fold) in the acute phase. This happens because other vasoactive factors besides chymase can degrade junction cells and cause plasma leakage in DHF patients.

\section{CONCLUSION}

There were no significant differences in chymase levels between groups NS1 (+) and NS1 (-). Significant differences in chymase levels were found between the control group with NS1 (+) and the control group with NS1 (-) in dengue virus infection. The decrease in platelets occurs very slightly below normal, with a slight increase in the number of monocyte cells.

\section{ACKNOWLEDGEMENT}

Thank you to Postgraduates School of Immunology Airlangga University Surabaya, Prof. Jusak Nugraha and Dr. Hartono Kahar for the support provided so that this research can be completed. To Ministry of Health for supporting funding and study permit.

\section{CONFLICT OF INTEREST}

We declared in this work not any conflict of interest.

\section{REFERENCE}

1. Kementrian, Kesehatan Rl. infodatin Demam Berdarah Dengue di Indonesia 2016.pdf. 2016.

2. Guzman MG, Gubler DJ, Izquierdo A, Martinez E, Halstead SB. Dengue infection. Nat Publ Gr. 2016;2:1-26. doi:10.1038/nrdp.2016.55

3. Yap SSL, Nguyen-khuong T, Rudd PM, Alonso S. Dengue Virus Glycosylation : What Do We Know? 2017;8(July):1-16. doi:10.3389/fmicb.2017.01415

4. Perng GC, Yoksan S, Pattanapanyasat K, Ahmed R, Pulendran B. Dengue Virus Infection Induces Expansion of a CD14+ CD16+ Monocyte Population that Stimulates Plasmablast Differentiation. 2015;16(1):115-127. doi:10.1016/j.chom.2014.06.001.

5. John ALS. Influence of Mast Cells on Dengue Protective Immunity and Immune Pathology. 2013;9(12):2011-2014. doi:10.1371/journal.ppat.1003783

6. Sala-cunill A. The Mast Cell, Contact, and Coagulation System Connection in Anaphylaxis. 2017;8(July):1-6. doi:10.3389/fimmu.2017.00846

7. $\quad$ Tissera H, Rathore APS, Leong Y, et al. Chymase Level Is a Predictive Biomarker of Dengue Hemorrhagic Fever in Pediatric and Adult Patients. 2018;216(April). doi:10.1093/infdis/jix447

8. Pejler G, Ro E, Waern I, Wernersson S. Review article Mast cell proteases : multifaceted regulators of inflammatory disease. 2018;115(24):4981-4991. doi:10.1182/blood-2010-01257287.

9. Wernersson S, Pejler G. Mast cell secretory granules: armed for battle. Nat Publ Gr. 2014;(June). doi:10.1038/nri3690

10. Badave GK, Swaroop PS, Rao PN. Importance of NS1 antigen detection and its association with platelet count for early diagnosis of dengue virus infection. 2015;4(3):779-784.

11. Siregar D, Djadja IM, Arminsih R. Analysis of the Risk Factors of Dengue Hemorrhagic Fever (DHF) In Rural Populations in Panongan Subdistrict, Tangerang 2016. 2017;2017:119-128. doi:10.18502/kls.v4i1.1373

12. Joshi AA, Gayathri BR, Muneer F. Dynamics of differential count in dengue. 2018;5(1):145150.

13. Jatmiko SW. Korelasi umur dengan kadar hematokrit, jumlah leukosit, dan trombosit pasien infeksi virus dengue. 2018;10:126. 
14. Utari FP, Efrida, Kadri H. Perbandingan Nilai Hematokrit dan Jumlah Trombosit antara Infeksi Dengue Primer dan Dengue Sekunder pada Anak di RSUP Dr. M. Djamil. 2018;7(1):118-123.

15. Tsai J, Chang J, Chang K, et al. Transient Monocytosis Subjugates Low Platelet Count in Adult Dengue Patients. 2017;457785. doi:10.1159/000457785 